\title{
MASAIL FIQHIYAH DALAM KONTEKS SOSIAL BUDAYA
}

\author{
Auffah Yumni \\ Dosen Tetap Fakultas Ilmu Tarbiyah dan Keguruan UIN Sumatera Utara
}

\begin{abstract}
Abstrak: ISLAM tidak diadreskan di dalam masyarakat yang hampa nilai-nilai sosial budaya, tetapi dialamatkan kepada masyarakat yang sudah sarat dengan nilai-nilai sosialbudaya. Kehadiran Islam tidak untuk serta merta harus menyingkirkan ajaran dan nilai-nilai yang sudah mapan.

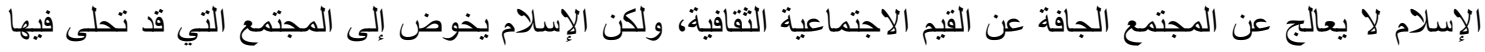

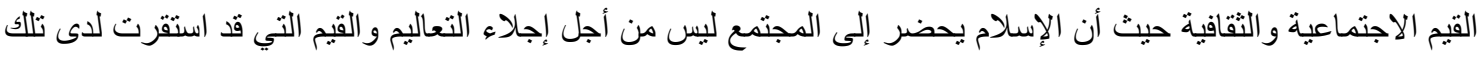

\section{A. PENDAHULUAN}

Allah swt mengartikulasikan ajaran Islam dengan menurunkan ayat-ayat Al-Quran secara berangsur-angsur (al-tadrij fi al-tasyri), memperkenalkan norma-norma hukum sedikit demi sedikit (al-taqlil al-taklif), dan berusaha menghidari benturan dan kesulitan (adam alharaj).

Rasulullah Saw juga memperkenalkan dirinya tidak sebagai "orang asing" di dalam masyarakatnya. Ia bahkan mengatakan: "Saya diutus untuk menyempurnakan akhlaq" (inni buitstu li utammi makarim al-akhlaq). Kata li utammim berarti menyempurnakan, bukan menyingkirkan nilai-nilai positif yang sudah ada sebelumnya.

Banyak sekali Nabi mengapresiasi kreatifitas lokal, misalnya: "Tuntutlah ilmu sampai ke negeri Cina", "Hikmah atau kebenaran ada di mana-mana, maka ambillah di mana pun kalian temukan", "Kalian lebih tahu urusan dunia kalian". Hadits-hadits ini menggambarkan betapa bijak Islam terhadap kearifan lokal.

Adanya kesan nilai-nilai Islam sebagai ajaran impor, agama pendatang, nilai-nilai asing, dan ajaran anti budaya lokal, perlu disikapi secara bijak. Kehadiran Islam di dalam sebuah masyarakat baru tidak bisa dipungkiri adanya gesekan yang muncul, dan ini berlaku untuk semua nilai, termasuk nilai-nilai social budaya asing di tempat itu juga mengalami hal yang sama. 
Namun pengalaman sejarah menunjukkan, kehadiran Islam di suatu tempat pada akhirnya diterima sebagai nilai-nilai ajaran inti di dalam masyarakat tersebut. Hal ini disebabkan karena Islam, secara subyektif dan obyektif bisa dikatakan, sebuah ajaran yang sesuai dengan nilai-nilai dasar kemanusiaan, menjunjung tinggi hak asasi, menghargai perbedaan jenis kelamin, etnik, agama, dan kepercayaan, ajarannya logis, masuk akal, dan sejalan dengan perkembangan sains moder.

Kehidupan sosial dari hari ke hari terus berubah bersama terjadinya perubahan kondisi geografis, kebudayaan, komposisi penduduk, ideologi dan penemuan-penemuan baru ilmu pengetahuan dalam kehidupan masyarakat. Hal ini akan terus berlangsung terus dan sangat menentukan peradaban umat manusia. Untuk menyikapi hal tersebut haruslah ada jalan untuk penyelesaiannya yaitu dengan ilmu masail fiqhiyah

Masalah fiqhiyah merupakan persoalan-persoalan yang muncul pada konteks kekinian dan persoalan tersebut belum pernah terjadi pada waktu yang lalu, karena adanya perbedaan situasi yang melingkupinya. Persoalan-persoalan tersebut dalam konteks sosial budaya berarti suatu kegiatan yang ada dalam suatu masyarakat yang dikenal dan dijalani oleh masyarakat dalam kehidupan dan berinteraksi abtar masyarakat. Seperti halnya Selamatan kandungan, nyanyian dan musik dan masik banyak lagi yang selama ini sudah dikenal dan dijalani oleh masyarakat itu terdapat kontroversi atas pelaksanaannya ada yang pro dan juga ada yang kontra. Karena merupakan hal yang baru setelah wafatnya Rasulullah saw.

\section{B. PEMBAHASAN}

\section{Pengertian Masail Fiqhiyah}

Masail Fiqhiyah adalah masaalah yang terkait dengan fiqih, dan yang dimaksud masallah fiqh pada term masail fiqhiyah ialah persoalan-persoalan yang muncul pada konteks kekinian sebagai refleksi kompleksitas problematika pada suatu tempat, kondisi dan waktu. Dan persoalan tersebut belum pernah terjadi pada waktu yang lalu, karena adanya perbedaan situasi yang melingkupinya

Pada masa Rasulullah, apabila ada masalah yang ada, masyarakat segera menanyakan pada Rasulullah SAW. Dan para sahabat atau para ahli Fuqaha pada masanya selalu berupaya 
menyelesaikan persoalan-persoalan baru dengan jalan ijtiihad berdasarkan nash Al-Qur'an atau al-sunnah. Penyelesaian mula-mula dicarikan jawabannya dari al-nash, bila tidak ditemukan maka akan diselesaiakn dengan jalan Ijma (kesepakatan para ahli atau melalui metode qiyas)

\section{Faktor-Faktor Kemunculan Masail Fiqhiyah}

a. Kondisi Geografis

Setiap daerah di belahan dunia ini pasti memiliki kondisi geografis yang berbeda. Ada yang memiliki udara tropis, subtropics dan sebagainya.

Perbedaan kondisi seperti ini lah yang akan memunculkan masalah yang berbeda-beda pula, terutama fiqh.

b. Struktur dan pola budaya masyarakat

Keberadaan suatu kebudayaan tidak bisa dipisahkan dari masyarakat dan dengan demikian kehadiran syari'at dalam hal ini hukum Islam (fiqh) tidak serta merta Didalam masyarakat yang sangat kental dengan nilai-nilai budayanya sangat sulit diterapkan nilai-nilai agama terutama sudut fiqih menggantikan posisi kebudayaan yang telah melekat pada masyarakat.

Apabila terjadi pembenturan antara keduanya, maka akan timbul persoalan baru yang kemudian disebut 'masailul fiqhiyah'. Contoh dalam masalah ini diantaranya selamatan kandungan (Tujuh Bulanan), tradisi mandi kembang.dan lain sebagainya.

c. Perkembangan Teknologi

Dewasaini kemajuan ilmu pengetahuan menunjukan prestasi yang cukup signufikan. Perkembangan ilmu pengetahuan dan teknologi modern selalu aktif menuju sasaran tepat dan berdampak positif sekaligus negative. Hasil kemampuan IPTEK dalam sekop umuum adalah salah satunyya computer. Alat ini dapat menunjukan arah kiblat, puasa, perhitungan zakat, warisan dan lainnya.

\section{Pengertian Sosial Budaya}


Sosial merupakan segala sesuatu yang mengenai masyarakat atau kemasyarakatan atau suka memerhatikan kepentingan umum. Budaya adalah berasal dari kata sans dan bodhya yang merupakan pikiran, akal dan budi. Budaya sering disebut tradisi atau adat istiadat. Sedangkan tradisi merupakan hal-hal yang dikenal dan dijalani oleh masyarakat dalam kehidupan dan interaksi mereka, baik berupa ucapan maupun meninggalkan sesuatu(Abdullah bin Qasim Al-Wasyli, Menyelami Samudera 20 Prinsip Hasan AlBanna, Era Intermedia, Solo, 2007, Hlm. 405)

Terciptanya sebuah kebudayaan dalam masyarakat bukan sekedar dari buah pikir dan budi manusia, tetapi juga dikarenakan adanya interaksi manusia dengan alam sekitarnya. Interaksi inilah yang menimbulkan adanya sosial budaya dimana tidak hanya interaksi manusia dengan alam tetapi interaksi manusia dengan manusia, manusia dengan Allah juga dapat menimbulkan sosial budaya.

Sehingga menurut pemakalah tradisi (budaya) merupakan kebiasaan yang dilakukan dan dijalani masyarakat secara terus menerus sehingga seakan-akan budaya merupakan hukum tertulis bagi mereka. Maka tidak heran lagi apabila masyarakat yang meyakini atau melakukan hal tersebut selalu mengkait-kaitkan dalam aplikasi kehidupannya.

Tradisi atau budaya terbagi menjadi dua ditinjau dari segi diterima atau tidaknya ,diantaranya Urf Shahih merupakan 'urf yang baik dan dapat diterima karena tidak bertentangan dengan syara'. Seperti mengadakan pertunangan sebelum melangsungkan akad nikah, hal seperti ini dipandang baik dan telah menjadi kebiasaan dalam masyarakat dan tidak bertentangan dengan syara'

Urf Fasid merupakan 'urf yang tidak baik dan tidak dapat diterima karena bertentangan dengan syara'. Seperti kebiasaan mengadakan sesajian untuk sebuah patung atau suatu tempat yang dipandang keramat. Hal ini tidak dapat diterima, karena berlawanan dengan ajaran Tauhid yang diajarkan agama Islam

Dapat disimpulkan sosial budaya merupakan segala hal yang dicipta oleh manusia dengan pemikiran dan budi nuraninya dalam kehidupan bermasyarakat yang dilakukan secara terus menerus pada waktu tertentu. 


\section{ISSN2086-4205}

\section{Contoh Masail Fiqhiyah dalam Konteks Sosial Budaya}

Ada beberapa contoh masail fiqhiyah dalam konteks sosial budaya diantaranya adalah sebagai berikut:

\section{Selamatan Kandungan (Tujuh Bulanan)}

Kehadiran seorang anak merupakan dambaan bagi sebuah keluarga. Anak merupakan kebahagiaan yang luar biasa, harta benda keluarga. Apalagi anak-anak yang shaleh shalehah. Penerus perjuangan orang tuanya. Untuk mewujudkan hal tersebut, berbagai cara calon orang tua maupun calon nenek kakek dilakukan. Salah satunya adalah walimatul hamli atau sering kita sebut dengan selamatan kandungan atau tingkeban (tujuh bulanan). Walimatul hamli dilakukan ketika kandungan beumur tujuh bulan bertetapan pada bulan purnama pada tanggal 14. Acara tersebut diawali dengan membaca shalawat al-barzanji dan ada yang membaca surat yusuf dan surat maryam.

Walimah berasal dari kata walm, yang artinya berkumpul. Secara syara' walimah digunakan pada makanan yang dibuat untuk mengungkapkan sebuah kebahagiaan. Bisa saja dia memperoleh kesenangan atau terlepas dari kesusahan. Baik kebahagiaan itu telah atau akan terjadi atau bisa jadi belum ada sebab yang melatar-belakangi. ( Mudir 'Am Ma'had Aly, Fiqh Realitas, Pustaka Belajar, 2005, Hlm. 247)

Menyelenggarakan walimah dengan segala macam bentuknya hukumnya sunnah. Sedangkan memenuhi undangan walimah hukumnya sunnah kecuali dalam pernikahan dimana hukumnya telah berubah menjadi wajib berdasarkan hadits Nabi Saw :

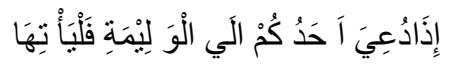

"Jika kalian diundang untuk menghadiri walimah, maka penuhilah".

Hadist tersebut hanya menjelaskan hukum walimatul al-'urs dengan konsekuensi hukumnya wajib. Sedangkan walimah al-hamli secara tekstual memang tidak ada dalam kitab-kitab fiqh. Akan tetapi kalau dilihat secara definisi walimatul al-hamli dikategorikan dalam fiqh. Oleh karena itu mengadakan walimatul al-hamli boleh-boleh saja. Bahkan dianjurkan karena mengandung muatan doa buat sang bayi yang ada dalam kandungan agar memperoleh 
keselamatan dan kelak menjadi anak yang baik dan berguna. . (Mudir 'Am Ma'had Aly, Fiqh Realitas, Pustaka Belajar, 2005, Hlm. 248)

Tradisi Mandi Kembang

Suatu tradisi yang tidak bertentangan dengan inti ajaran agama, tentunya Islam akan menjustifikasi. Dalam walimah al-hamli, mungkin baca al-Qur'an dan shalawat no problembahkan dianjurkan. Yang menjadi persoalan adalah tradisi mandi kembang yang dilakukan oleh sebagian masyarakat.

Metode dalam mandi kembang sendiri bermacam-macam. Dan masing-masing mengandung makna filosofis. Misalnya yaitu : sang istri duduk dikursi plastic atau terbuat dari kayu yang tidak dipaku, maknanya suapaya si jabang bayi bisa lahir dengan mudah dan selamat; separuh tubuh sang istri dibalut dengan kain kafan kemudian disiram dengan air yang dicampur dengan beraneka bunga dan wewangian, maknanya supaya sang jabang bayi kelak bisa mengharumkan nama keluarga; gayung yang dipakai terbuat dari batok kelapa yang masih ada isinya beserta gagangnya terbuat dari pohon beringin, maknanya supaya si jabang bayi bertutur bahasa yang halus dan bisa mengayomi masyarakat; calon nenek mengambil kelapa kuning dan ditimang-timang bagaikan bayi kemudian diletakkan di tempat tidur, maknanya waktu melahirkan nanti agar dipermudah oleh Allah.. ( Mudir 'Am Ma'had Aly, Fiqh Realitas, Pustaka Belajar, 2005, Hlm. 246)

Itu semua tergantung atau kembali pada pola pikir masyarakat masing-masing. Sejauhmana anggapan mereka terhadap tardisi tersebut. Jika hanya menganggapnya sebagai suatu tradisi yang turun temurun tanpa ada keyakinan sebagai sebuah ajaran agama tentu tidak ada masalah. Karena dalam praktik tradisi mandi kembang tidak menyalahi praktik islam.

Manusia hanya bisa berbuat sesuai dengan kemampuannya. Demikian pula dalam memohon pada Allah. Tak sedikit orrang awam yang tidak mengerti bagaimana berdoa dengan kata-kata. Apalagi dengan wirid-wirid yang begitu sering kita sebut dengan istilahnjelimet. Yang mereka bisa hanya dengan perbuatan asalkan tidak bertentangan dengan syari'at islam.

Tradisi Bersih Desa (Upacara Sadran)

Bersih desa merupakan salah satu upacara adat jawa yang diselenggarakan setelah para petani panen padi. Hal ini dimaksudkan untuk mengungkapkan rasa syukur karena 
tanaman padi telah berhasil dipanen dan telah menghasilkan panenan yang memuaskan. Disamping itu, sadran juga merupakan penghormatan terhadap para leluhur yang telah meninggal dunia dan mendo'akan agar dosa-dosanya diampuni oleh Tuhan, serta agar yang di tinggalkan selalu mendapatkan keselamatan, murah rezeki dan mudah sandang pangan serta agar desa terhindar dari bencana.

Bagi masyarakat jawa, kegiatan tahunan yang bernama sadranan ini merupakan ungkapan refleksi sosial keagamaan. Hal ini dilakukan dalam rangka menziarahi makam para leluhur. Ritual ini dipahami sebagai bentuk pelestarian warisan tradisi dan budaya nenek moyang. Tradisi ini merupakan simbol adanya hubungan dengan leluhur, sesama dan yang maha kuasa, serta sebuah ritual yang mencampurkan budaya lokal dan nilai-nilai islam.

Adapun tujuan dari bersih desa yaitu agar masyarakat sekitar mengetahui bagaimana sejarah dan perjuangan "danyang" dalam membuat, memberi nama dan membentuk desa. Selain itu nyadranan juga menjadi ajang silaturahmi keluarga dan sekaligus menjadi transformasi sosial, budaya dan keagamaan. Sedangkan hikmahnya dari bersih desa diantaranya dapat mempererat selahturahmi, menanamkan sifat gotong royong, saling mendoakan satu dengan yang lainnya, dan bersama-sama dapat merasakan susah maupun senang orang lain.

Adapun persiapan sebelum acara dimulai antara lain adalah membersihkan makammakam leluhur dan mempersiapkan tempat untuk selamatan (kenduri). Sedangkan antusias warga dalam upacara bersih desa ini dapat dilihat dari persiapan warga membuat makanan dan jajanan sebagai salah satu unsur pelengkap ritual tersebut. Disamping dipakai munjung atau ater-ater kepada sanak saudara yang lebih tua dan tetangga dekat. Hal itu dilakukan sebagai ungkapan solidaritas kepada sesama.

Seni Lukis, Seni Pahat

Persoalan patung sudah ada sejak zaman dulu, seiring dengan munculnya peradaban manusia. Patung merupakan hasil kreatifitas dalam melukiskan apa yang ada disekitarnya. Dalam ilmu budaya ia termasuk kategori seni, cipta dan karsa manusia. Misalnya saat ini yaitu patung liberty yang tinggi menjulang langit di New York, Amerika yang menggambarkan seorang perempuan cantik lengkap dengan segala atributnya sedang memegang obor kebebasan. Patung tersebut menjadi symbol kebebasan orang-orang negeri Paman Sam. Hal ini jelas berbeda dengan kenyataan masa dulu, utamanya sebelum periode 
ilmu pengetahuan. Saat itu patung sebagai berhala yang mereka sembah. Tentunya fiqh memberikan tanggapannya dengan arif yaitu hal tersebut dilarang. Adapun macam-macam tashwir mencakup dua hal diantaranya:

1. Tashwir tiga dimensi yaitu tashwir yang mempunyai bayang-bayang yang disebut tamatsil (patung)

2.Tashwir yang tidak memiliki bayang-bayang atau lukisan biasa.

Dengan demikian, larangan membuat tashwir adalah larangan untuk membuat patung. Para ulama juga melarang pembuatan patung akan tetapi pelarangan tersebut tidak berlaku mutlak. Ada beberapa kriteria khusus yang harus dipenuhi diantaranya, patung itu menggambarkan sesuatu yang bernyawa, patung yang tidak menggambarka hal ini jelas dibolehkan. Bentuk patung harus sempurna, yang tidak sempurna boleh-boleh saja dibuat.

Bicara tentang kebenaran hukum, termasuk hukum membuat dan menggunakan patung harus memerhatikan illat (reason) sebuah hukum. Illat dilarangnya hukum membuat patung adalah karena musyabahah (menyerupakan diri dengan Allah SWT). Pembuat patung memfungsikan diri sebagai pencipta makhluk, sebuah posisi yang dapat menyerupai posisi Tuhan dimana menyerupakan patung yang dibuat dengan dzat Pencipta. Ini mengingatkan bahwa patung yang dibuat tersebut akan dijadikan sesembahan yang menyamai Allah SWT sebagai zat yang patut disembah. Larangan membuat patung di atas dianggap wajar mengingat kondisi sosiokultural bangsa Arab saat itu rata-rata masih sangat primitive yang dikenal dengan sebutan jahiliyah. . ( Mudir 'Am Ma'had Aly, Fiqh Realitas, Pustaka Belajar, 2005, Hlm. 265)

Melihat setting sejarah pengharaman diatas, pada zaman sekarang illat tersebut tampaknya jauh dari kenyataan. Sebab sangat tidak logis orang-orang modern seperti sekarang masih berpikiran primitive seperti saat turunnya hukum pelarangan membuat patung berhala. Illat musyabahah tidak dijumpai pada zaman sekarang. Patung dibuat tidak untuk kepentingan musyabahah.

\section{PENUTUP}

Keberadaan suatu kebudayaan tidak bisa dipisahkan dari masyarakat dan dengan demikian kehadiran syari' at dalam hal ini hukum Islam (fiqh) tidak serta merta menggantikan posisi kebudayaan yang telah melekat pada masyarakat. 
Begitu pula hubungan antara keagamaan dengan budaya berada pada posisi yang saling membutuhkan dan bersifat timbal balik. Dalam konteks ini agama membutuhkan budaya untuk lebih mudah masyarakat dalam memahami ajaran agama.

Dengan keilmuan masail fiqhiyahdiharapkan mampu memahami dengan baik tentang problema-problema yang timbul dalam fiqh Isla, memberikan kemampuan untuk membahas dan memechkan masalah-masalah fiqh yang aktual dan memasyarakatkannya dengan pendekatan yang luas, yamg tidak hanya terfokus pada teks-teks klasik akan tetapi juga pada pendekatan-pendekatan rasional (Abdurrahman kasdi, Masail Fiqhiyyah, Nora Media Enterprise, Kudus, 2011, hal 7) tentunya juga dengan memperthatikan sosial budaya masyarakat.

Allahu A'lam bishawab.

\section{DAFTAR PUSTAKA}

Abdullah bin Qasim Al-Wasyli,Menyelami Samudera 20 Prinsip Hasan Al-Banna, Era Intermedia, Solo, 2007

Kamal Muchtar, dkk, Ushul Fiqh, PT Dana Bhakti Wakaf, Yogyakarta, 1995

Mudir 'Am Ma'had Aly, Fiqh Realitas, Pustaka Belajar, 2005

Abdurrahman kasdi, Masail Fiqhiyyah, Nora Media Enterprise, Kudus, 2011 